\title{
Odile Malas, La Vièrge au gré des jours. Les concours de poésie mariale à Caen 1527-1794
}

\section{Filippo Fassina}

\section{(2) OpenEdition}

1 Journals

\section{Edizione digitale}

URL: http://journals.openedition.org/studifrancesi/8208

DOI: ERREUR PDO dans/localdata/www-bin/Core/Core/Db/Db.class.php L.34 : SQLSTATE[HYO00]

[2006] MySQL server has gone away

ISSN: 2421-5856

\section{Editore}

Rosenberg \& Sellier

\section{Edizione cartacea}

Data di pubblicazione: 1 mai 2009

Paginazione: 156

ISSN: 0039-2944

\section{Notizia bibliografica digitale}

Filippo Fassina, «Odile Malas, La Vièrge au gré des jours. Les concours de poésie mariale à Caen 1527-1794», Studi Francesi [Online], 157 (LIII | I) | 2009, online dal 30 novembre 2015, consultato il 07 janvier 2021. URL: http://journals.openedition.org/studifrancesi/8208; DOI: https://doi.org/10.4000/ studifrancesi.8208

Questo documento è stato generato automaticamente il 7 janvier 2021.

\section{(c) (i) $\odot$}

Studi Francesi è distribuita con Licenza Creative Commons Attribuzione - Non commerciale - Non opere derivate 4.0 Internazionale. 


\title{
Odile Malas, La Vièrge au gré des jours. Les concours de poésie mariale à Caen 1527-1794
}

\author{
Filippo Fassina
}

\section{NOTIZIA}

ODILE MALAS, La Vièrge au gré des jours. Les concours de poésie mariale à Caen 1527-1794, Melfi, Libria, 2000 («Babele», 10), pp. 317.

1 Nel 1527 l'Università di Caen crea il «Puy de Palinods», un'istituzione incaricata di organizzare un concorso annuale di poesia su di un argomento prestabilito: la Vergine e il suo culto, radicato sin dal XII secolo in Normandia. L'A. offre un panorama storico e culturale del «Puy de Palinods» e del concours, sottolineando lo stretto legame fra l'Università di Caen e il contesto religioso dell'epoca, profondamente condizionato dalla Riforma. Il presente studio, oltre a ripercorrere le tappe storiche della suddetta istituzione dalle origini al 1794, dedica ampio spazio alle tematiche e ai generi letterari espressi dai componimenti del concours, offrendo anche numerosi esempi testuali. Da notare una tavola cronologica, un ricco apparato bibliografico e un'appendice contenente svariate illustrazioni di testi a stampa. 